\title{
Yield characteristics of cherry tomato cultivated with and without shading screen at different irrigation levels ${ }^{1}$
}

\author{
Edgo Jackson Pinto Santiago ${ }^{2}$, Gertrudes Macário de Oliveira ${ }^{2}$, \\ Mário de Miranda Vilas Boas Ramos Leitão ${ }^{3}$, Ruy de Carvalho Rocha ${ }^{2}$, Allan Victor Araújo Pereira ${ }^{2}$
}

\section{ABSTRACT}

The use of shading screen in vegetable crops sensitive to the radiation excess, associated with the effective water use via irrigation, allows for yield gains. This study aimed to evaluate the yield characteristics of cherry tomato cultivated with and without shading screen and different irrigation levels. A randomized block design was used, in a $4 \times 2$ factorial arrangement, with four irrigation levels $(140 \%, 160 \%, 180 \%$ and $200 \%$ of the reference evapotranspiration - ETo) and two cherry tomato hybrids (Wanda and Dolcetto). The irrigation level corresponding to $200 \%$ of the ETo provided the highest values for number of flowers and clusters formed, number of fruits per plant and fruit diameter. The Wanda hybrid was more fruitful, with a higher emission of clusters, while Dolcetto was more floriferous. The use of shade screen for cultivating cherry tomato provides an increase in the yield characteristics, if compared to the cultivation in open areas.

KEYWORDS: Solanum lycopersicum; shading; effective water use.

\section{INTRODUCTION}

Tomato is a vegetable of great economic and social importance in Brazil, and it is cultivated in several regions of the country (Franca et al. 2017). However, one of the major challenges in the tomato cultivation is obtaining good quality fruits with a high yield (Cardoso et al. 2018). On the other hand, considering the current scenario, regarding the use of ecologically correct products, the growing demand for pesticide-free fruits has helped cherry tomato crops to gain prominence in the dynamics of family agriculture; and the products of these crops have been

\section{RESUMO}

Características de rendimento de tomate cereja cultivado com e sem tela de sombreamento e diferentes lâminas de irrigação

O uso de tela de sombreamento no cultivo de hortaliças sensíveis ao excesso de radiação, associado ao uso eficiente de água via irrigação, possibilita ganhos de produtividade. Objetivouse avaliar características de rendimento de tomate cereja cultivado com e sem o uso de tela de sombreamento e diferentes lâminas de irrigação. Utilizou-se delineamento em blocos casualizados, em esquema fatorial 4 x 2, com quatro lâminas de irrigação (140\%, $160 \%, 180 \%$ e $200 \%$ da evapotranspiração de referência - ETo) e dois híbridos de tomate cereja (Wanda e Dolcetto). A lâmina de irrigação correspondente a $200 \%$ da ETo proporcionou maiores valores para número de flores e cachos formados, número de frutos por planta e diâmetro de fruto. O híbrido Wanda foi mais frutífero, com maior emissão de cachos, enquanto o Dolcetto mostrou-se mais florífero. O uso de tela de sombreamento no cultivo de tomate cereja proporciona incremento nas características de rendimento, se comparado ao cultivo em áreas abertas.

PALAVRAS-CHAVE: Solanum lycopersicum; sombreamento; uso eficiente de água.

gaining visibility and consumer acceptance, as their origin is known and they are therefore more reliable.

However, the vegetable production may be limited in regions characterized by a high incidence of solar radiation and, consequently, high temperatures, such as the semiarid region of northeastern Brazil. In this region, open-field grown tomatoes are restricted to the season of the year with the lowest incidence of solar radiation and temperature. According to Franca et al. (2017), in hot regions, the best tomato yields are obtained in the autumn-winter.

Overall, extreme climatic conditions elicit responses from vital plant mechanisms, especially

1. Received: May 20, 2018. Accepted: Oct. 04, 2018. Published: Nov. 12, 2018. DOI: 10.1590/1983-40632018v4853064.

2. Universidade do Estado da Bahia, Departamento de Tecnologia e Ciências Sociais, Juazeiro, BA, Brasil.

E-mail/ORCID: edgoj@hotmail.com/0000-0003-3981-7635,gmacariodeoliveira@yahoo.com.br/0000-0002-7587-5800, rcrocha@uneb.br/0000-0001-9669-6687, allan.v1997@gmail.com/0000-0001-8707-1140.

3. Universidade Federal do Vale do São Francisco, Colegiado de Engenharia Agrícola e Ambiental, Juazeiro, BA, Brasil. E-mail/ORCID: mario.miranda@univasf.edu.br/0000-0002-6696-2195. 
those associated with photosynthesis and effective water use, and might result in significant yield losses. Therefore, alternative technologies are required, especially when the species to be produced is sensitive to adverse climatic conditions, which is the case of tomatoes.

Hence, techniques such as protected cultivation rise as an alternative, as they allow for obtaining suitable micrometeorological conditions for the crops and for introducing effective cultivation methods (Duarte et al. 2010). A protected environment contributes both with an increased crop yield and with improved product quality and reduced water consumption (Viol et al. 2017).

In the region of Juazeiro, Bahia state, Brazil, the use of shading screens has risen as an alternative method for adverse climatic conditions that have hampered the open-field tomato cultivation, especially in the second half of the year (Rocha 2007).

Shading screens decrease the radiation incidence and improve the spectral quality of the light that goes through their mesh, influencing the radiation flux inside the protected environment, with impacts on the morphophysiological dynamics of plants, which, in turn, affect crop yield characteristics, such as flowering and fruiting. Nevertheless, the protected cultivation does not ensure a reduced expenditure and increased yields by itself. Factors related to nutrition, genetics of the material and water supply must also be at suitable levels (Silva et al. 2013).

Given that tomato is sensitive to the excess of solar radiation, is a water demanding crop (Patanè et al. 2011), being water deficiency the factor that most affects yield (Santana et al. 2009), and that this crop reacts negatively to both the excess of water and to water deficit (Marouelli \& Silva 2006), this study aimed to evaluate the yield characteristics of cherry tomato hybrids cultivated with and without shading screen and under different irrigation levels.

\section{MATERIAL AND METHODS}

Two experiments were conducted at the Universidade do Estado da Bahia (09'24'50"S and $\left.40^{\circ} 30^{\prime} 10^{\prime \prime} \mathrm{W}\right)$, in Juazeiro, Brazil, from January 05 to April 22, 2017. The experimental areas were situated side by side, with $12 \mathrm{~m} \mathrm{x} 25 \mathrm{~m}$ and oriented from east to west. In one of them, a $4.0 \mathrm{~m}$ covering structure was built to create a protected environment (shaded area), using ChromatiNet ${ }^{\circledR}$ Silver screen (35\% of shading), with a horizontal roof and an open space on the sides ( $2.5 \mathrm{~m}$ from the soil surface). The other area was not covered (open field).

In both experimental areas, a randomized block design was used, in a 4 × 2 factorial arrangement, with four irrigation levels $(140 \%, 160 \%, 180 \%$ and $200 \%$ of the reference evapotranspiration - ETo) and two cherry tomato hybrids (Wanda and Dolcetto, both with undetermined growth habit). Regarding the levels used, it is worth noting that the irrigation levels had been initially designed (when the experiment was installed, in October 2016) to be either higher and lower than $100 \%$ of the ETo. However, these levels were not enough to meet the atmospheric demand and, therefore, the plants were under stress (leaf wilting) even with the highest level (120\% of the ETo). Hence, installing a new experiment with higher rates was required.

Cultivation was performed in pots with capacity for $8 \mathrm{~L}$, with $1.10 \mathrm{~m}$ x $0.40 \mathrm{~m}$ spacing, containing soil classified as Red Latosol, in a 4:1 ratio, with commercial substrate. This kind of cultivation was chosen due to its potential to be employed in areas where soil cultivation is impracticable due to salinization (which is common in semiarid regions). That proportion was chosen due to the scarcity of studies that report this form of cultivation under protected environment in the semiarid region.

The chemical analysis of the mixture of soil with substrate showed the following characteristics: organic matter $=22.5 \mathrm{~g} \mathrm{~kg}^{-1} ; \mathrm{Ca}^{2+}=2.9 \mathrm{cmol}_{\mathrm{c}} \mathrm{dm}^{-3}$; $\mathrm{Mg}^{2+}=1.3 \mathrm{cmol}_{\mathrm{c}} \mathrm{dm}^{-3} ; \mathrm{Na}^{+}=0.1 \mathrm{cmol}_{\mathrm{c}} \mathrm{dm}^{-3} ; \mathrm{K}^{+}=$ $0.36 \mathrm{cmol} \mathrm{dm}^{-3} ; \mathrm{H}+\mathrm{Al}=3.14 \mathrm{cmol}_{\mathrm{c}} \mathrm{dm}^{-3} ; \mathrm{Al}^{+}=$ $0.05 \mathrm{cmol}_{\mathrm{c}}^{\mathrm{c}} \mathrm{dm}^{-3}$; sum of bases $=4.62 \mathrm{cmol}_{\mathrm{c}} \mathrm{dm}^{-3}$; cation exchange capacity $=7.8 \mathrm{cmol}_{\mathrm{c}} \mathrm{dm}^{-3}$; base saturation $=60 \% ; \mathrm{P}=30.74 \mathrm{mg} \mathrm{dm}^{-3} ; \mathrm{pH}=5.3$.

The irrigation system used was dripping. A PCJ pressure compensating emitter with $3.0 \mathrm{~L} \mathrm{~h}^{-1}$ outflow was placed above each pot. The test for determining the uniformity of water supply was performed in each experiment (Keller \& Karmeli 1975), and the result was a coefficient of distribution uniformity (CDU) of 0.94 .

To define the irrigation levels, reference evapotranspiration (ETo) data were used, determined based on the Penman-Monteith method (FAO standard) and obtained from the meteorological station of the Universidade do Estado da Bahia, located $50 \mathrm{~m}$ away from the experimental area. Once the ETo $\left(\mathrm{mm} \mathrm{day}^{-1}\right)$ was obtained, after incorporating 
incremental levels of $140 \%, 160 \%, 180 \%$ and $200 \%$, the crop evapotranspiration was determined according to the equation: $\mathrm{ETc}=\mathrm{Kc} *$ ETo, where ETc is the crop evapotranspiration $\left(\mathrm{mm} \mathrm{day}^{-1}\right)$ and $\mathrm{Kc}$ the coefficient of cultivation (non-dimensional). The coefficients of cultivation $(\mathrm{Kc})$ proposed by Macêdo \& Alvarenga (2005) were used for the different tomato development stages.

The gross rate (GR) applied (mm day ${ }^{-1}$ ) was calculated using the equation: $\mathrm{GR}=\mathrm{ETc} / \mathrm{CDU}$ and the intensity of application $\left(\mathrm{I}_{\mathrm{a}}\right)$ was obtained using the expression: $\mathrm{I}_{\mathrm{a}}=\mathrm{q} / \mathrm{A}$, where $q$ is the outflow of the dripping emitter $\left(3.0 \mathrm{~L} \mathrm{~h}^{-1}\right)$ and $A$ the pot area $\left(0.0415 \mathrm{~m}^{2}\right)$, while the irrigation time (Ti), in hours, was calculated using the equation: $T_{i}=G R / I_{a}$.

Fertilizations were performed weekly via fertigation, based on the results of the soil chemical analysis and fertigation recommendations for protected-grown tomatoes proposed by Trani et al. (2015).

Foliar fertilizations were also performed using a manual costal pulverizer, to prevent nutritional deficiencies and physiological disorders. Plants were pulverized with $0.1 \%$ of boric acid and $0.3 \%$ of zinc sulphate, and the applications started approximately at 25 days after transplanting (DAT) the seedlings to the pots. Then, the pulverizations were repeated every two weeks. The Metalosate ${ }^{\circledR}$ Crop-Up ${ }^{\circledR}$ foliar fertilizer was also used at a dose of $20 \mathrm{~mL} / 20 \mathrm{~L}$ of water, as well as $6 \mathrm{~g} \mathrm{~L}^{-1}$ of $\mathrm{N}$ calcium solution. Magnesium deficiencies, such as "yellow leaf curl", were prevented by performing fortnightly foliar pulverizations with a solution of $1.5 \mathrm{~g}$ of magnesium sulphate. For that, urea $\left(5 \mathrm{~g} \mathrm{~L}^{-1}\right)$ was added to stimulate the magnesium absorption by leaves.

Until seedlings were established, the same water level was applied in both experimental areas, and they started being differentiated at 12 DAT. Plants were tutored using ribbons and, after the first forking, they were conducted on two stems and side shoots were eliminated.

The following variables were evaluated: number of flowers, number of clusters formed and number of fruits per plant, at 44 and 57 DAT. At harvest time, the transverse and longitudinal diameters of fruits were also evaluated, using a digital caliper.

Data were submitted to a test of normality of errors (Shapiro \& Wilk 1965). The homogeneity of variances was performed in each environment, using the Bartlett's test. The Stata/MP 14.0 software was used in both tests. A joint analysis of the experiments was performed initially, applying an analysis of variance using the F-test of Snedecor at $5 \%$ of probability, with the Sisvar software. For significant effects, linear regression analyses were performed for quantitative data and an analysis of comparison of means was performed for qualitative data, using the Tukey test at $5 \%$ of probability.

\section{RESULTS AND DISCUSSION}

Regarding the yield characteristics, the different irrigation levels did not have a significant effect on the number of clusters in the studied seasons, and there was a significant effect only for the isolated factors 'hybrids' and 'environments'. At 44 DAT, both hybrids and environments led to a significant different number of clusters. On the other hand, at 57 DAT, only the factor 'hybrids' was significant (Table 1). The Wanda hybrid stood out, as it had a higher mean number of clusters (18.91 at 44 DAT and 51.24 at 57 DAT), which exceeds Dolcetto in more than $32 \%$ and $20 \%$, respectively (Table 1 ). These results are similar to those obtained by Silva et al. (2011), who evaluated the productive performance of heat-tolerant cherry tomato lineages. The authors observed that the CLN1561A and CLN1558A lineages had, on average, 11 and 17.5 clusters per plant, and they concluded that the first lineage was one of the most suitable for cherry tomato cultivation and commercialization, due to its higher yield and total soluble solid content, mostly in regions with a hotter climate.

The shaded environment presented around $66 \%$ more clusters than the open one (Table 1). This fact is possibly due to the attenuated solar radiation provided by the shading screen and improvements

Table 1. Mean number of clusters in cherry tomato hybrids (Wanda and Dolcetto) at 44 and 57 days after transplanting (DAT) and in each cultivation environment.

\begin{tabular}{lllc}
\hline \multirow{2}{*}{ Source of variation } & & \multicolumn{2}{c}{ DAT } \\
\cline { 3 - 4 } & & 44 & 57 \\
\hline \multirow{2}{*}{ Hybrid } & Wanda & $18.91 \mathrm{~A}^{*}$ & $51.24 \mathrm{~A}$ \\
& Dolcetto & $14.30 \mathrm{~B}$ & $42.40 \mathrm{~B}$ \\
\hline \multirow{2}{*}{ Environment } & Shaded & $20.74 \mathrm{~A}$ & \\
& Open & $12.46 \mathrm{~B}$ & \\
\hline
\end{tabular}

* Means followed by the same uppercase letter in the column, for each source of variation and period, do not differ from each other using the Tukey test at $5 \%$ of probability. 
in the spectral quality at the canopy level, with influence on the synthesis of photoassimilates and in the hormonal balance.

At 44 DAT, there was a significant effect of the factors 'levels', 'hybrids' and 'environments' on the variable 'number of flowers', and only 'levels' and 'hybrids' had effects at 57 DAT (Figure 1).

There were increasing linear adjustments in all the evaluated periods (Figure 1). In other words, the number of flowers increased as the water replacement levels increased. These results are in accordance with those found by Silva et al. (2014), who evaluated agronomic aspects of tomato cultivated under different water replacement rates, in the semiarid of the Paraíba state, Brazil. At that time, the authors observed a higher number of flowers in plants submitted to the treatment with the highest water replacement ( $150 \%$ of the ETo). On the other hand, the results obtained in the present study were lower than those observed by Silva et al. (2013), who evaluated protected grown tomato under water replacements, and obtained, on average, 157 flowers per plant, when the rate of $136 \%$ of crop evapotranspiration was applied.

It is worth noting that, in the study by Silva et al. (2013), the mean monthly maximum temperature was $33.5^{\circ} \mathrm{C}$ and the mean monthly relative humidity was $83 \%$, while the mean maximum temperature was approximately $35^{\circ} \mathrm{C}$ and the mean relative air humidity was $51 \%$ in the present study, in both environments, with little differences between them throughout the crop cycle. Therefore, this climatic condition certainly contributed to preclude pollen grains and cause a higher floral bud abortion and, consequently, floral abscission.

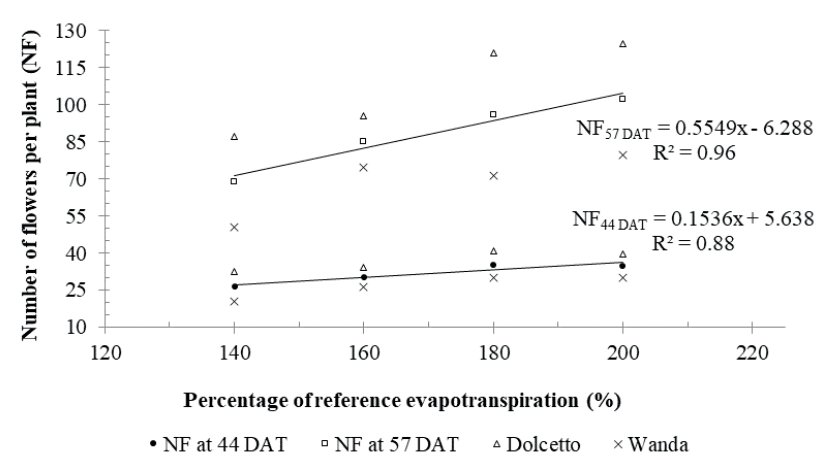

Figure 1. Number of flowers per plant, as a function of irrigation levels, for cherry tomato hybrids. DAT: days after transplanting.
The mean values for number of flowers observed in each cherry tomato hybrid and in each cultivation environment are present in Table 2. The Dolcetto hybrid showed a higher flower emission ability than Wanda, with mean values of 36.79 and 107.12, respectively at 44 and 57 DAT. The shaded environment was the most suitable, providing adequate conditions to a higher flower emission per tomato plant, exceeding the open environment by $60 \%$.

At 57 DAT, the effect of different levels applied on the number of fruits per plant of the cherry tomato hybrids provided a significant adjustment to the linear model (Figure 2). This means that, at every $20 \%$ of variation in the water replacement rate, starting at $140 \%$ of the ETo, fruits increased by approximately 2.3 per plant. The linear adjustment obtained in the present study differs from that observed by Silva et al. (2013), who studied water replacement levels in tomato, since they obtained a quadratic adjustment for the number of fruits per plant.

Table 2. Number of flowers observed in cherry tomato hybrids (Wanda and Dolcetto) at 44 and 57 days after transplanting (DAT) and in each cultivation environment.

\begin{tabular}{llrr}
\hline \multirow{2}{*}{ Source of variation } & & \multicolumn{2}{c}{ DAT } \\
\cline { 3 - 4 } & & 44 & \multicolumn{1}{c}{57} \\
\hline \multirow{2}{*}{ Hybrid } & Wanda & $26.71 \mathrm{~B}^{*}$ & $68.97 \mathrm{~B}$ \\
& Dolcetto & $36.79 \mathrm{~A}$ & $107.12 \mathrm{~A}$ \\
\hline \multirow{2}{*}{ Environment } & Shaded & $39.17 \mathrm{~A}$ & \\
& Open & $24.33 \mathrm{~B}$ & \\
\hline
\end{tabular}

* Means followed by the same uppercase letter in the column, in each period and for each source of variation, do not differ from each other using the Tukey test at $5 \%$ of probability.

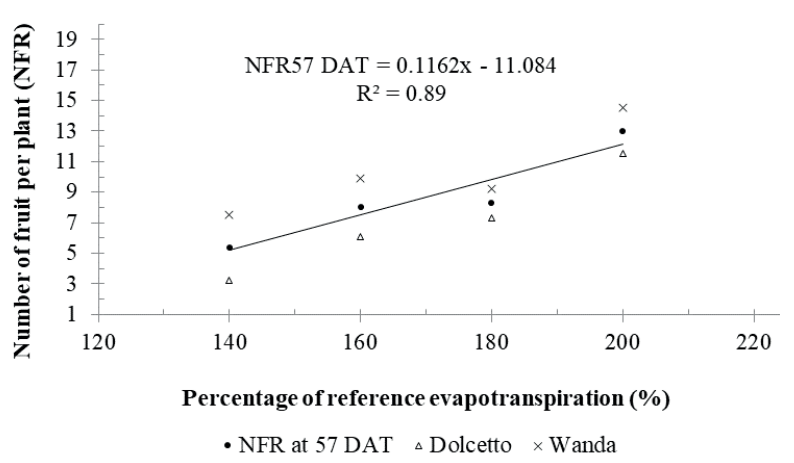

Figure 2. Behavior of the number of fruits per plant, as a function of irrigation levels of cherry tomato hybrids, at 57 days after transplanting (DAT). 
Although there was no significant effect for the interaction between 'levels' and 'hybrids' at 57 DAT, Wanda showed, on average, a higher number of fruits per plant than Dolcetto (Figure 2). On average, in the variation from $140 \%$ to $200 \%$ of the ETo, the number of fruits in cherry tomato hybrids increased by $41 \%$, with $28 \%$ corresponding to Dolcetto and $52 \%$ corresponding to Wanda. Silva et al. (2014) observed a $66 \%$ increase in the number of fruits per plant, with the variation in the water replacement rate from $50 \%$ to $150 \%$ of the reference evapotranspiration. Santana et al. (2009) state that a water replacement rate lower or higher than $100 \%$ of the plant hydric consumption negatively affects the number of fruits yielded, what was not observed in the present study. This indicates that the increasing water rates applied were within the water demand range for this crop.

Wanda showed higher mean values for number of fruits per plant (4.6 and 10.3, respectively at 44 and 57 DAT), while Dolcetto had, on average, 1.7 times less fruits per plant than Wanda (Table 3 ). When analyzing the cultivation environment (Table 3), it is noticeable that the highest number of flowers provided by the shaded environment (Table 2) resulted in a higher number of fruits per plant in this environment. Overall, shading provided a higher fruit set (of up to 1.5 times more fruits per plant) than the open field cultivation. Otoni et al. (2012), who evaluated the agronomic yield and quality of tomato hybrids under different shading levels, observed that the luminosity influenced fruiting; i.e., the total number of fruits and mean number of fruits per plant varied according to the shading percentages studied, and the maximum values of 25.03 and 6.18 fruits per plant were obtained for $13.4 \%$ and $25.4 \%$ of shading, respectively.

Table 3. Number of fruits per plant for each cherry tomato hybrid and cultivation environment, at 44 and 57 days after transplanting (DAT).

\begin{tabular}{llcr}
\hline \multirow{2}{*}{ Source of variation } & & \multicolumn{2}{c}{ DAT } \\
\cline { 3 - 4 } & & 44 & 57 \\
\hline \multirow{2}{*}{ Hybrid } & Wanda & $4.60 \mathrm{~A}^{*}$ & $10.30 \mathrm{~A}$ \\
& Dolcetto & $1.55 \mathrm{~B}$ & $7.03 \mathrm{~B}$ \\
\hline \multirow{2}{*}{ Environment } & Shaded & $4.16 \mathrm{~A}$ & $9.94 \mathrm{~A}$ \\
& Open & $1.99 \mathrm{~B}$ & $7.40 \mathrm{~B}$ \\
\hline
\end{tabular}

* Means followed by the same uppercase letter in the column, in each period and for each source of variation, do not differ from each other using the Tukey test at $5 \%$ of probability.
The development of the mutual effect of interaction between 'hybrids' and 'environments' on the number of fruits per plant, at 44 and 57 DAT, are shown in Table 4. It is evident that the time with the highest number of fruits per plant was 57 DAT. It is also evident that the shaded environment favored Wanda, causing it to have the highest fruit set of rates per plant (6.61 at 44 DAT and 13.03 at 57 DAT), if compared to its cultivation without shading.

On the other hand, the number of fruits per plant for Dolcetto was not influenced by the cultivation environments, which were statistically equal at 44 and 57 DAT. These results are the opposite of those observed by Otoni et al. (2012), who generally concluded that shaded environments provided a better performance of the evaluated tomato hybrids. However, both findings are in accordance to the extent that they show that open-grown plants have a lower growth and reduced number of fruits per plant.

Overall, Wanda had the highest mean number of fruits per plant, if compared to Dolcetto, in both environments and seasons. There is an exception, though, in the open environment at 44 DAT, when the number of fruits per plant was statistically the same for both hybrids.

A significant individual effect of the sources of variation 'irrigation levels' and 'hybrids' was observed on the transverse and longitudinal fruit diameters. In the latter, there was also a significant contribution of the cultivation environment, which provided a different longitudinal diameter to cherry tomato fruits.

The transverse and longitudinal fruit diameters of the tomato hybrids, studied according to the irrigation levels, are respectively presented in Figures 3 and 4, which also show an increasing

Table 4. Mutual effect of cultivation environment and cherry tomato hybrid on the number of fruits per plant, at 44 and 57 days after transplanting (DAT).

\begin{tabular}{ccrc}
\hline \multirow{2}{*}{ DAT } & \multirow{2}{*}{ Environment } & \multicolumn{2}{c}{ Hybrids } \\
\cline { 3 - 4 } & & Wanda & Dolcetto \\
\hline \multirow{2}{*}{44} & Shaded & $6.61 \mathrm{Aa}^{*}$ & $1.72 \mathrm{Ab}$ \\
& Open & $2.59 \mathrm{Ba}$ & $1.38 \mathrm{Aa}$ \\
\hline \multirow{2}{*}{57} & Shaded & $13.03 \mathrm{Aa}$ & $6.84 \mathrm{Ab}$ \\
& Open & $7.58 \mathrm{Ba}$ & $7.23 \mathrm{Aa}$ \\
\hline
\end{tabular}

* Means followed by the same uppercase letter in the column or lowercase letter in the row, at each period, do not differ statistically using the Tukey test at $5 \%$ of probability. 
linear behavior with the increased irrigation levels. For every $20 \%$ of variation in the water replacement rate, starting at $140 \%$ of the ETo, there were increases of approximately $1.2 \mathrm{~mm}$ and $1.4 \mathrm{~mm}$, respectively in the transverse and longitudinal diameters. The linear adjustments obtained in the present study differ from those noticed by Silva et al. (2014), who observed quadratic adjustments for the variables analyzed; however, they agree with those observed by Silva et al. (2013) and Koetz et al. (2010). The absence of quadratic behavior in the present study suggests that, although the irrigation levels were higher than $100 \%$ of the ETo, not even the highest of them (200\%) was capable of causing a depleting effect in the transverse and longitudinal diameters of cherry tomato fruits.

Although no significant effect of the interaction between 'levels' and 'hybrids' was observed on the transverse and longitudinal diameters of cherry tomato fruits, Wanda had, on average, a higher transverse diameter than Dolcetto (Figure 3). In the variation from $140 \%$ to $200 \%$ of the ETo, the

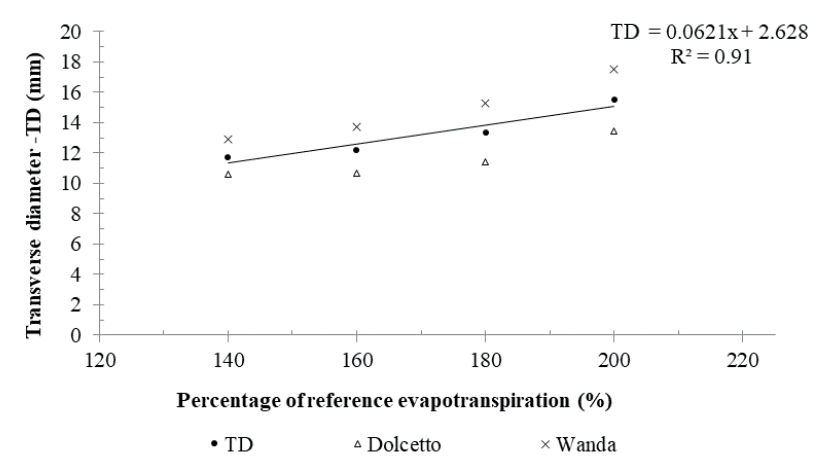

Figure 3. Behavior of the transverse fruit diameter of cherry tomato hybrids, according to the irrigation levels.

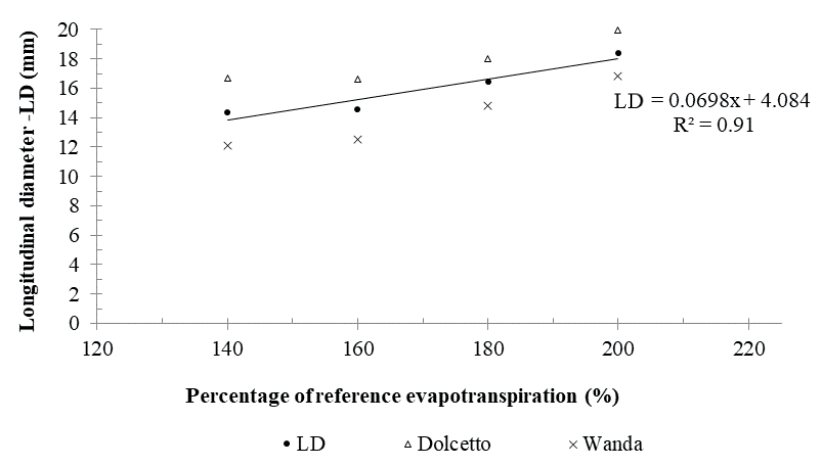

Figure 4. Behavior of the longitudinal fruit diameter of cherry tomato hybrids, according to the irrigation levels. transverse diameter of the cherry tomato hybrids increased by $32.1 \%$, on average, with $27.2 \%$ corresponding to the variation in Dolcetto and $35.9 \%$ corresponding to Wanda. These results differ from those found by Silva et al. (2013), Silva et al. (2014) and Koetz et al. (2010), who observed increases of $60 \%, 66 \%$ and $4.6 \%$ in the transverse diameter of tomato fruits, respectively, which corresponded to the variation in the water replacement rate from the lowest to the highest level.

Regarding the longitudinal diameter, Dolcetto had the highest mean values (Figure 4). On average, the increase in the longitudinal diameter of the hybrids was approximately $28 \%$, considering the variation in the irrigation level from $140 \%$ to $200 \%$ of the ETo. Koetz et al. (2010) observed mean increases of only $5 \%$ in the longitudinal diameter of tomato fruits, under irrigation replacement levels between $50 \%$ and $125 \%$ of the rate required to increase the soil moisture to field capacity.

Wanda had the highest mean transverse diameter and the lowest longitudinal diameter, with $14.85 \mathrm{~mm}$ and $14.08 \mathrm{~mm}$, respectively (Table 5). There was no influence of the cultivation environment on the transverse diameter. However, the open environment enabled higher longitudinal diameters.

In addition, the shaded environment generally provided the lowest mean diameters (Table 5). This result might be associated to the faster soil desiccation in this environment, when compared to the open area, thus limiting the water content available for cell expansion. This is likely due to a longer period for stomatal opening, due to an attenuated solar radiation in the shaded environments and, consequently, a higher transference of water vapor to the atmosphere. A decrease in the cell expansion due to stomatal closure caused by soil dryness was reported by Pimentel \& Rossielo (1995). Stomatal closure is one of the first defense lines against dryness, as it is an

Table 5. Transverse and longitudinal diameters of cherry tomato hybrids in the different cultivation environments.

\begin{tabular}{llcc}
\hline \multirow{2}{*}{ Source of variation } & & \multicolumn{2}{c}{ Fruit diameter (mm) } \\
\cline { 3 - 4 } & & Transverse & Longitudinal \\
\hline \multirow{2}{*}{ Hybrid } & Wanda & $14.85 \mathrm{~A}^{*}$ & $14.08 \mathrm{~B}$ \\
& Dolcetto & $11.52 \mathrm{~B}$ & $17.82 \mathrm{~A}$ \\
\hline \multirow{2}{*}{ Environment } & Shaded & $12.82 \mathrm{~A}$ & $15.23 \mathrm{~B}$ \\
& Open & $13.55 \mathrm{~A}$ & $16.66 \mathrm{~A}$ \\
\hline
\end{tabular}

* Means followed by the same uppercase letter in the column, for each source of variation, do not differ from each other using the Tukey test at $5 \%$ of probability. 
attempt to maintain a suitable water content in the tissues for a longer period (Silva et al. 2003).

The behavior of the cherry tomato hybrids (Dolcetto with a larger longitudinal diameter and Wanda with a higher transverse diameter) is inherent to the genetic characteristics of each hybrid, since Dolcetto fruits are longer, grape-like, and Wanda fruits are flatter (round-shaped). Fernandes et al. (2007), who proposed size and weight classes for cherry tomato fruits in Jaboticabal, São Paulo state, Brazil, using the Sindy cultivar, hybrid F1, suggested that cherry tomatoes are classified as small (2P caliber) when the highest fruit diameter lays within the range from greater than $20-25 \mathrm{~mm}$, and with weight between $5 \mathrm{~g}$ and $10 \mathrm{~g}$. The transverse diameters obtained by both hybrids in the present study were lower than $20 \mathrm{~mm}$ (Figure 3 and Table 5); therefore, they are not even classified as small fruits.

Size is an important characteristic for tomato commercialization, since a reduced diameter might hinder the product sale (Silva et al. 2014). Loos et al. (2009) believe that several factors might interfere in the tomato fruit quality, but the major factor is water deficiency, since it reduces turgidity and, consequently, the cell expansion process. It is also worth to note that the water deficit changes physiological processes such as cell elongation, gas exchanges in leaves and transport through the phloem and membranes, limiting the cell expansion and expediting the leaf senescence (Taiz \& Zeiger 2013).

The water status in the plant influences fruit growth, mostly under a high evaporation demand, as either growth or reduction in the tomato fruit size are highly related with daily increase and decrease of water potential in the plant, which, in turn, is intimately related with the amount of water in the soil (Johnson et al. 1992, Soares et al. 2011). Silva et al. (2014) emphasize that tomato is sensitive both to water deficit and excess in the soil.

The determining factor that most certainly affected the appearance of tomato fruits with small diameters was the fact that the present experiment was conducted in pots with a small volumetric capacity, black color and containing soil classified as a Red Latosol. These conditions created a favorable microclimate that, associated with the high atmospheric demand, characterized mostly by the high incidence of solar radiation and low relative air humidity, provided a high evaporation rate, thus consequently reducing the water content available and the nutrient absorption, with a negative effect on yield characteristics.

Reduced transverse diameters of tomato fruits with decreased water availability were reported by Soares et al. (2011 and 2013), Candido et al. (2015) and Pacheco (2017). According to Chevalier et al. (2011), the tomato fruit size depends on the cell growth rate and duration. According to Pacheco (2017), considering that the water availability directly influences the plant physiological processes, a reduced fruit size might be explained by an increased water tension in the soil, which is correlated with a reduced mean fruit mass. Bezerra (2015) states that the lack of water during fruit formation causes its growth to cease.

\section{CONCLUSIONS}

1. The irrigation level corresponding to $200 \%$ of the ETo provides higher values for the number of flowers and clusters formed, number of fruits per plant and fruit diameter for cherry tomato;

2. The Wanda hybrid showed to be more fruitful, with a higher cluster emission, while Dolcetto was more floriferous;

3. The use of shading screen in cherry tomato crops provides increased yield characteristics, if compared to cultivation in an open area.

\section{REFERENCES}

BEZERRA, R. R. Manejo da fertirrigação na produção de minitomate em ambiente protegido. 2015. 87 f. Dissertação (Mestrado em Agronomia) - Universidade Federal de Goiás, Goiânia, 2015.

CANDIDO, V. et al. Growth and yield promoting effect of artificial mycorrhization on field tomato at different irrigation regimes. Scientia Horticulturae, v. 187, n. 1, p. 35-43, 2015.

CARDOSO, F. B. et al. Yield and quality of tomato grown in a hydroponic system, with different planting densities and number of bunches per plant. Pesquisa Agropecuária Tropical, v. 48, n. 4, p. 340-349, 2018.

CHEVALIER, C. et al. Elucidating the functional role of endoreduplication in tomato fruit development. Annals of Botany, v. 107, n. 7, p. 1159-1169, 2011.

DUARTE, G. R. B. et al. Medida e estimativa da evapotranspiração do tomateiro cultivado sob adubação orgânica em ambiente protegido. Semina: Ciências Agrárias, v. 31, n. 3, p. 563-574, 2010. 
FERNANDES, C.; CORÁ, J. E.; BRAZ, L. T. Classificação de tomate-cereja em função do tamanho e peso dos frutos. Horticultura Brasileira, v. 25, n. 2, p. 275-278, 2007.

FRANCA, R. J. F.; LEITÃO, M. M. V. B. R.; CAMPECHE, L. F. S. M. Produtividade do tomate cereja em ambiente protegido e céu aberto em função das lâminas e intermitências de irrigação. Revista Brasileira de Agricultura Irrigada, v. 11, n. 2, p. 1364-1370, 2017.

JOHNSON, R. W.; DIXON, M. A.; LEE, D. R. Water relations of the tomato during fruit growth. Plant and Cell Environment, v. 18, n. 10, p. 947-953, 1992.

KELLER, J.; KARMELI, D. Trickle irrigation design. Glendora: Rain Bird Sprinkler Manufacturing, 1975.

KOETZ, M. et al. Caracterização agronômica e ${ }^{\circ}$ Brix em frutos de tomate industrial sob irrigação por gotejamento no sudoeste de Goiás. Revista Brasileira de Agricultura Irrigada, v. 4, n. 1, p. 14-22, 2010.

LOOS, R. A.; CALIMAN, F. R. B.; SILVA, D. J. H. Enxertia, produção e qualidade de tomateiro cultivado em ambiente protegido. Ciência Rural, v. 39, n. 1, p. 232235, 2009 .

MACÊDO, L. S.; ALVARENGA, M. A. R. Efeito de lâminas de água e fertirrigação potássica sobre o crescimento, produção e qualidade de frutos de tomateiro em ambiente protegido. Ciência e Agrotecnologia, v. 29, n. 2, p. 296-304, 2005.

MAROUELLI, W. A.; SILVA, W. L. C. Irrigação por gotejamento do tomateiro industrial durante o estádio de frutificação, na região do Cerrado. Horticultura Brasileira, v. 24, n. 3, p. 342-346, 2006.

OTONI, B. S. et al. Produção de híbridos de tomateiro cultivados sob diferentes porcentagens de sombreamento. Revista Ceres, v. 59, n. 6, p. 816-825, 2012.

PACHECO, A. B. Tomateiro cereja sob disponibilidades hídricas e doses de potássio com irrigação semiautomatizada em ambiente protegido. 2017. 86 f. Dissertação (Mestrado em Engenharia Agrícola) - Universidade Federal de Mato Grosso, Rondonópolis, 2017.

PATANÈ, C.; TRINGALI, S.; SORTINO, O. Effects of deficit irrigation on biomass, yield, water productivity and fruit quality of processing tomato under semi-arid Mediterranean climate conditions. Scientia Horticulturae, v. 129, n. 4, p. 590-596, 2011.

PIMENTEL, C.; ROSSIELO, R. O. P. Entendimento sobre relações hídricas. In: SIMPÓSIO INTERNACIONAL SOBRE ESTRESSE AMBIENTAL: O MILHO EM PERSPECTIVA, 1995, Belo Horizonte. Anais... Embrapa/ CNPMS, 1995. p. 131-146.
ROCHA, R. C. Uso de diferentes telas de sombreamento no cultivo protegido do tomateiro. 2007. $105 \mathrm{f}$. Tese (Doutorado em Horticultura) - Faculdade de Ciências Agronômicas, Universidade Estadual Paulista, Botucatu, 2007.

SANTANA, M. J.; VIEIRA, T. A.; BARRETO, A. C. Efeito dos níveis de reposição de água no solo na produtividade do tomateiro. Horticultura Brasileira, v. 27, n. 2, p. 1378-1384, 2009.

SHAPIRO, S. S.; WILK, M. B. An analysis of variance test for normality complete samples. Biometrika, v. 52, n. 3-4, p. 591-611, 1965.

SILVA, A. C. et al. Avaliação de linhagens de tomate cereja tolerantes ao calor sob sistema orgânico de produção. Revista Caatinga, v. 24, n. 3, p. 33-40, 2011.

SILVA, B. A.; SILVA, A. R.; PAGIUCA, L. G. Cultivo protegido: em busca de mais eficiência produtiva. Revista Hortifruti Brasil, n. 132, p. 10-18, 2014.

SILVA, E. C. et al. Comportamento estomático e potencial da água da folha em três espécies lenhosas cultivadas sob estresse hídrico. Acta Botanica Brasilica, v. 17, n. 2, p. 231-246, 2003.

SILVA, J. M. et al. Cultivo do tomateiro em ambiente protegido sob diferentes taxas de reposição da evapotranspiração. Revista Brasileira de Engenharia Agrícola e Ambiental, v. 17, n. 1, p. 40-46, 2013.

SOARES, L. A. A. et al. Componentes de produção do tomateiro sob lâminas de irrigação nas fases fenológicas. Revista Verde de Agroecologia e Desenvolvimento Sustentável, v. 8, n. 3, p. 84-90, 2013.

SOARES, L. A. A. et al. Crescimento do tomateiro e qualidade física dos frutos sob estresse hídrico em ambiente protegido. Revista Verde de Agroecologia e Desenvolvimento Sustentável, v. 6, n. 3, p. 203-212, 2011.

TAIZ, L.; ZEIGER, E. Fisiologia vegetal. 5. ed. Porto Alegre: Artmed, 2013.

TRANI, P. E. et al. Calagem e adubação do tomate de mesa. Campinas: Instituto Agronômico, 2015.

VIOL, M. A. et al. Déficit hídrico e produção do tomate cultivado em ambiente protegido. Revista Brasileira de Agricultura Irrigada, v. 10, n. 7, p. 1244-1253, 2017. 